\title{
Effect of chronic smoking on lipid peroxidation and antioxidant status in gastric carcinoma patients
}

\author{
Palanisamy Pasupathi ${ }^{1}$, Palanisamy Chinnaswamy ${ }^{2}$, Ganesan Saravanan ${ }^{3}$ and Utharasamy Senthil Kumar ${ }^{4}$ \\ ${ }^{1}$ Institute of Laboratory Medicine, K.G. Hospital and Postgraduate Medical Institute, Coimbatore 641018, Tamil Nadu; \\ ${ }^{2}$ Institute of Laboratory Medicine, Kovai Medical Center and Hospital, Coimbatore 641014, Tamil Nadu; ${ }^{3}$ Department of \\ Biochemistry and Biotechnology, Faculty of Science, Annamalai University, Annamalainagar 608002, Tamil Nadu; \\ ${ }^{4}$ Institute of Laboratory Medicine, Bio Line Research Institute, Coimbatore 641014, Tamil Nadu, India. \\ email:drppasupathi@gmail.com
}

\begin{abstract}
The effect of chronic cigarette smoking on lipid peroxidation and antioxidant status in 100 newly diagnosed patients with gastric cancer was studied. Equal number of age- and sex-matched healthy control subjects was taken as control. The level of plasma and erythrocyte thiobarbituric acid reactive substances (TBARS) was markedly increased in both the gastric cancer patients when compared to control subjects. The activities of enzymatic and non-enzymatic antioxidants were significantly decreased in both (smokers and non-smokers) gastric cancer groups when compared to control subjects. Comparatively, the increased TBARS level and decreased antioxidants level was observed in smokers than non-smoking gastric cancer patients. The present study highlights the occurrence of lipid peroxidation and possible breakdown of antioxidant status in cigarette smoking, which may subsequently increase the possibility of initiation and progression of gastric cancer.
\end{abstract}

\section{Introduction}

Gastric cancer is a leading cause of illness and death from cancer worldwide, with nearly a million new cases diagnosed each year. The incidence of gastric cancer is different throughout the world and $60 \%$ of deaths from gastric cancer occur in developing countries ${ }^{1,2}$. In India, earlier studies showed relatively higher incidence of stomach cancer among males in Chennai during 1997 to 1998 (age-adjusted rate $(\mathrm{AAR})=13.2 / 10^{5}$ ) and among women it is next to cancer of the breast $\left(\mathrm{AAR}=7.0 / 10^{5}\right)^{3}$.

Cigarette smoking has been strongly implicated as a risk factor for chronic obstructive pulmonary disease, cancer and atherosclerosis. Cigarette smoke is known to contain a large number of oxidants, which are capable of causing an increase in the generation of various reactive oxygen species (ROS) like superoxide $\left(\mathrm{O}_{2}^{\bullet}\right)$, hydrogen peroxide $\left(\mathrm{H}_{2} \mathrm{O}_{2}\right)$, hydroxyl $(\mathrm{OH})$ and peroxyl (ROO $)^{\bullet}$ radicals. These ROS in turn are capable of initiating and promoting oxidative damage in the form of lipid peroxidation ${ }^{4}$. Tobacco smoke contains some deadly carcinogenic chemicals formed from natural components of the tobacco plants. Tobacco smoke contains a variety of carcinogen including N-nitroso compounds and nitrogen oxides that may promote endogenous formation of $\mathrm{N}$-nitroso compounds, which have been linked to gastric carcinogenesis ${ }^{5}$. Free radical-mediated processes have been implicated in tobacco carcinogenesis. Cigarette smoke is a main source of free radicals and can activate endogenous ROS-related enzymes. It has been hypothesized that many of the adverse effects of smoking may result from oxidative damage to critical biologic substances. Such damage could result both from oxidants present in cigarette smoke and from the activation of phagocytic cells that generate $\operatorname{ROS}^{6}$.

Antioxidants constitute the foremost defense system that limit the toxicity associated with free radicals. Cells have developed a comprehensive array of antioxidants that act co-operatively in vivo to combat the deleterious effects of free radicals. Low levels of enzymatic and non-enzymatic antioxidants in the circulation have been found to be associated with an increased risk of cancer. The plasma and erythrocyte are excellent model for studies on lipid peroxidation and antioxidant defense mechanisms due to its simplicity, easy availability and ease of isolation. The present study was, therefore, undertaken to determine the effects of chronic smoking on the extent of lipid peroxidation and the status of antioxidants in gastric cancer patients. 


\section{Materials and Methods}

Study population: One hundred newly diagnosed gastric cancer patients viz; non-smokers $(n=50)$ and smokers $(n=50)$ and age-matched healthy controls viz; non-smokers $(n=50)$ and smokers $(n=50)$ participated in this study were selected from Kovai Medical Centre and Hospital, and K.G. Hospital and Postgraduate Medical Institute, Coimbatore, Tamil Nadu, India, during the period July 2005 to July 2007. All primary gastric cancers were diagnosed by histological examination (using gastric biopsy samples). The study population (agematched male subjects) was selected on inclusion and exclusion criteria. All healthy smokers smoking more than 25 cigarettes per day for a period of two years have been included in this study. The patients were not receiving chemotherapy or radiotherapy at the time of the study. The study excluded patients with Helicobacter pylori infection and other medical illnesses including endocrine, metabolic or autoimmune disorders that may reflect on free radical status. Informed consent was obtained from all the participants. General health characteristics such as age, sex, smoking status, alcohol consumption, and dietary habits, particularly as related to preference for spicy or salty foods, were investigated by a self-administered questionnaire. Studies were approved by the Bioethics Committee of the K.G. Hospital and Postgraduate Medical Institute (decision $\mathrm{KGH} / 164 / 2001$ ), and informed consent was obtained from all patients.

Blood collection and erythrocyte lysate preparation: Blood samples were collected by venous puncture in heparinized tubes and the plasma was separated by centrifugation at $1,000 \mathrm{x} \mathrm{g}$ for $15 \mathrm{~min}$. After centrifugation, the buffy coat was removed and the packed cells were washed three times with physiological saline. A known volume of the erythrocytes was lysed with hypotonic phosphate buffer ( $\mathrm{pH}$ 7.4). The hemolysate was separated by centrifugation at 2,500 $\times \mathrm{g}$ for $15 \mathrm{~min}$ at $2^{\circ} \mathrm{C}$.

Estimation of biochemical parameters: The level of blood glucose was estimated by fully automated clinical chemistry analyzer (Hitachi 912, Boehringer Manuheim, Germany). Total hemoglobin and blood cell (RBC and WBC) count were determined using automated hematology analyzer (ABX Pentra XL 80, USA)

Estimation of lipid peroxidation: Lipid peroxides were estimated by measurement of thiobarbituric acid reactive substances (TBARS) in plasma by the method of Yagi, ${ }^{7}$ the pink chromogen produced by the reaction of thiobarbituric acid with malondial- dehyde, a secondary product of lipid peroxidation was estimated. The absorbance of clear supernatant was measured against reference blank at $535 \mathrm{~nm}$. Lipid peroxidation was estimated by measurement of TBARS in erythrocyte by the method of Donnan ${ }^{8}$.

Assay of enzymatic antioxidants: Superoxide dismutase (SOD) was assayed utilizing the technique of Kakkar et al. ${ }^{9}$ based on inhibition of the formation of nicotinamide adenine dinucleotide, phenazine methosulfate and amino blue tetrazolium formazan. A single unit of enzyme was expressed as $50 \%$ inhibition of nitro blue tetrazolium reduction $/ \mathrm{min} / \mathrm{mg}$ protein. CAT was assayed colorimetrically at $620 \mathrm{~nm}$ and expressed as $\mu$ moles of $\mathrm{H}_{2} \mathrm{O}_{2}$ consumed $/ \mathrm{min} / \mathrm{mg}$ protein as described by $\operatorname{Sinha}^{10}$. The reaction mixture (1.5 $\mathrm{mL}$ ) contained $1.0 \mathrm{~mL}$ of $0.01 \mathrm{M}$ phosphate buffer $\mathrm{pH} 7.0,0.1 \mathrm{~mL}$ of erythrocyte lysate (supernatant) and $0.4 \mathrm{~mL}$ of $2 \mathrm{M} \mathrm{H}_{2} \mathrm{O}_{2}$. The reaction was stopped by the addition of $2.0 \mathrm{~mL}$ of dichromate-acetic acid reagent $(5 \%$ potassium dichromate and glacial acetic acid were mixed in 1:3.

GPx activity was measured by the method described by Rotruck et $\mathrm{al}^{11}$. Briefly, reaction mixture contained $0.2 \mathrm{~mL}$ of $0.4 \mathrm{M}$ Tris- $\mathrm{HCl}$ buffer $\mathrm{pH} 7.0,0.1 \mathrm{~mL}$ of $10 \mathrm{mM}$ sodium azide, $0.2 \mathrm{~mL}$ of erythrocyte hemolysate (homogenized in $0.4 \mathrm{M}$, Tris- $\mathrm{HCl}$ buffer, $\mathrm{pH} 7.0$ ), $0.2 \mathrm{~mL}$ glutathione, 0.1 $\mathrm{mL}$ of $0.2 \mathrm{mM}$ hydrogen peroxide. The contents were incubated at $37^{\circ} \mathrm{C}$ for $10 \mathrm{~min}$. The reaction was arrested by $0.4 \mathrm{~mL}$ of $10 \%$ TCA, and centrifuged. Supernatant was assayed for glutathione content by using Ellmans reagent [19.8 $\mathrm{mg}$ of 5,5'-dithiobisnitro benzoic acid (DTNB) in $100 \mathrm{~mL}$ of $0.1 \%$ sodium nitrate].

The GST activity was determined spectrophotometrically by the method of Habig et $\mathrm{al}^{12}$. The reaction mixture $(3 \mathrm{ml})$ contained $1.0 \mathrm{~mL}$ of 0.3 $\mathrm{mM}$ phosphate buffer ( $\mathrm{pH} 6.5), 0.1 \mathrm{~mL}$ of $30 \mathrm{mM}$ 1-chloro-2,4-dinitrobenzene (CDNB) and $1.7 \mathrm{~mL}$ of double distilled water. After preincubating the reaction mixture at $37^{\circ} \mathrm{C}$ for $5 \mathrm{~min}$, the reaction was started by the addition of $0.1 \mathrm{~mL}$ of erythrocyte hemolysate and $0.1 \mathrm{~mL}$ of glutathione as substrate. The absorbance was followed for 5 $\min$ at $340 \mathrm{~nm}$.

Estimation of non-enzymatic antioxidants: Plasma reduced glutathione level (GSH) was determined by the method of Ellman ${ }^{13}$. $1.0 \mathrm{~mL}$ of supernatant was treated with $0.5 \mathrm{~mL}$ of Ellmans reagent and 3.0 $\mathrm{mL}$ of phosphate buffer $(0.2 \mathrm{M}, \mathrm{pH} 8.0)$. The absorbance was read at $412 \mathrm{~nm}$. Glutathione peroxidase activity was expressed as $\mu \mathrm{g}$ of GSH consumed $/ \mathrm{min} / \mathrm{mg}$ protein and reduced glutathione 
as $\mathrm{mg} / 100 \mathrm{~g}$ of hemolysate. Erythrocyte GSH content was determined with dithionitrobenzoic acid using the method described by Beutler and Kelley $^{14}$, and was expressed in $\mu \mathrm{mol} \mathrm{GSH} / \mathrm{L}$ hemolysate. The lower detection limit was 5 $\mu \mathrm{mol} / \mathrm{L}$, and the coefficient of variation was $1 \%$ at $20 \mu \mathrm{mol} / \mathrm{L}$.

Plasma $\beta$-carotene was estimated by the method of Bradle and Hombeck ${ }^{15}$. Proteins were precipitated with ethanol and the carotenes were extracted into light petroleum. The intensity of the yellow color due to carotene was read directly at $450 \mathrm{~nm}$ using a violet filter. Vitamin $\mathrm{E}$ was measured by the method of Baker et al. ${ }^{16}$, on the basis of the reduction of ferric ions to ferrous ions by vitamin $\mathrm{E}$ and the formation of a red colored complex with 2.2'-dipyridyl at $520 \mathrm{~nm}$. Vitamin $\mathrm{C}$ was estimated by the method of Roe and Kuether ${ }^{17}$. This involves oxidation of ascorbic acid by copper followed by treatment with 2,4-dinitrophenylhydrazine that undergoes rearrangement to form a product with absorption maximum at $520 \mathrm{~nm}$.

Statistical analysis: All the results were expressed as mean \pm S.D. for fifty subjects in each group. The statistical significance was evaluated by oneway analysis of variance (ANOVA) using SPSS version 10 (SPSS, Cary, North Carolina, USA). Duncan's Multiple Range Test (DMRT) ${ }^{18}$ obtained individual comparisons. A $p$ value of $\leq 0.05$ was considered a significant difference between groups.

\section{Results and Discussion}

The decrease in body mass index (BMI) in gastric cancer patients; non-smokers $\left(30 \pm 9.8 \mathrm{~kg} / \mathrm{m}^{2}\right)$, smokers $\left(26 \pm 7.8 \mathrm{~kg} / \mathrm{m}^{2}\right)$ when compared to healthy control subjects; non-smokers (35 \pm 9.7 $\left.\mathrm{kg} / \mathrm{m}^{2}\right)$ and smokers $\left(33 \pm 10.2 \mathrm{~kg} / \mathrm{m}^{2}\right)$ was statistically significant (Table I). An increased number of hypertensive or diabetes was observed in gastric cancer patients compared with health control subjects.

RBC count, total hemoglobin and hematocrit were significantly decreased in both non-smokers and smokers carcinoma group patients when compared with healthy subjects (smokers and non-smokers) (Table II). However, the levels of fasting blood glucose in gastric cancer patients and healthy control subjects did not differ significantly. In addition, WBC counts significantly increased in gastric carcinoma patients when compared to healthy control subjects, but on the other hand, there was no significant difference in smokers and non-smoking subjects.

Lipid peroxidation indicated by TBARS level was significantly higher in both plasma and erythrocytes in patients with gastric cancer compared to healthy control subjects (Table III). The concentration of TBARS was significantly greater in smokers as compared to non-smokers in the gastric cancer patients. The decrease in the levels of plasma and erythrocyte GSH in gastric cancer patients compare with healthy control subjects was statistically significant. On the other hand, the level of GSH was significantly decreased in smokers as compared to non-smoking gastric cancer patients.

The decreased levels of erythrocyte antioxidants SOD, CAT, GPx and GST in gastric cancer subjects as compared to healthy controls were statistically significant (Table IV). In addition, a drastically decrease in the levels of erythrocyte enzymatic antioxidants (SOD, CAT, GPx) were observed in smokers than non-smoking gastric cancer patients. Significantly decreased in the levels of plasma antioxidants ( $\beta$ carotene $\mathrm{E}$ and $\mathrm{C}$ ) in gastric cancer subjects as compared to healthy controls (Table V). The mean level of plasma antioxidants ( $\beta$ carotene $\mathrm{E}$ and $\mathrm{C}$ ) was drastically decreased in smokers as compared to non-smoking gastric cancer patients.

Table I: Demographic characteristics of healthy subjects and gastric cancer patients

\begin{tabular}{|c|c|c|c|c|}
\hline Parameters & $\begin{array}{c}\text { Control } \\
\text { Non-smokers } \\
\end{array}$ & $\begin{array}{c}\text { Control } \\
\text { Smokers } \\
\end{array}$ & $\begin{array}{l}\text { Gastric cancer } \\
\text { Non-smokers }\end{array}$ & $\begin{array}{c}\text { Gastric cancer } \\
\text { Smokers }\end{array}$ \\
\hline Total number of subjects & 50 & 50 & 50 & 50 \\
\hline Mean age (years) & $56 \pm 12.4^{\mathrm{a}}$ & $54 \pm 14.5^{\mathrm{a}}$ & $59 \pm 11.7^{\mathrm{c}}$ & $53 \pm 10.4^{\mathrm{d}}$ \\
\hline Sex (male) & $100 \%$ & $100 \%$ & $100 \%$ & $100 \%$ \\
\hline Body mass index $\left(\mathrm{kg} / \mathrm{m}^{2}\right)$ & $35 \pm 9.7^{\mathrm{a}}$ & $33 \pm 10.2^{a}$ & $30 \pm 9.8^{c}$ & $26 \pm 7.8^{\mathrm{d}}$ \\
\hline Diagnosis & - & - & Gastric adenocarcinoma & Gastric adenocarcinoma \\
\hline Smokers & - & $100 \%$ & - & $100 \%$ \\
\hline Alcohol & - & $2 \%$ & $1.2 \%$ & $2 \%$ \\
\hline Hypertension & $1.5 \%$ & $7.2 \%$ & $12 \%$ & $16 \%$ \\
\hline Diabetes mellitus & - & $1.3 \%$ & $2.25 \%$ & $2.41 \%$ \\
\hline
\end{tabular}


Table II: Blood picture of healthy control and gastric cancer subjects

\begin{tabular}{|c|c|c|c|c|c|}
\hline Parameters & $\begin{array}{c}\text { Fasting glucose } \\
(\mathrm{mg} / \mathrm{dL})\end{array}$ & Hemoglobin $(\mathrm{g} / \mathrm{dL})$ & Hematocrit (\%) & RBC count $\left(10^{6} / \mu \mathrm{L}\right)$ & $\begin{array}{c}\text { WBC count } \\
\left(10^{6} / \mu \mathrm{L}\right)\end{array}$ \\
\hline \multicolumn{6}{|l|}{ Control } \\
\hline Smokers & $97.6 \pm 7.33^{\mathrm{a}}$ & $13.5 \pm 1.15^{\mathrm{a}}$ & $46 \pm 6.8^{\mathrm{a}}$ & $5.32 \pm 0.77^{\mathrm{a}}$ & $8.2 \pm 3.1^{\mathrm{a}}$ \\
\hline \multicolumn{6}{|l|}{ Gastric cancer } \\
\hline
\end{tabular}

Values are given as mean \pm S.D from 50 subjects in each group: Values not sharing a common superscript letter differ significantly at $\mathrm{p}<0.05$ (DMRT)

Table III: Plasma and erythrocyte TBARS and GSH in healthy control and gastric cancer subjects

\begin{tabular}{|c|c|c|c|c|}
\hline Parameters & $\begin{array}{c}\text { Plasma TBARS } \\
(\mathrm{nmoL} / \mathrm{mL})\end{array}$ & $\begin{array}{c}\text { Erythrocyte TBARS } \\
(\mathrm{pmol} / \mathrm{mg} \mathrm{Hb})\end{array}$ & $\begin{array}{c}\text { Plasma GSH } \\
(\mathrm{mg} / \mathrm{dL})\end{array}$ & $\begin{array}{c}\text { Erythrocyte GSH } \\
(\mathrm{mg} / \mathrm{dL})\end{array}$ \\
\hline \multicolumn{5}{|l|}{ Control } \\
\hline Non-smokers & $3.06 \pm 0.23^{\mathrm{a}}$ & $3.26 \pm 0.61^{\mathrm{a}}$ & $38.98 \pm 1.67^{\mathrm{a}}$ & $56.27 \pm 7.52$ \\
\hline Smokers & $4.60 \pm 0.17^{b}$ & $4.55 \pm 0.12^{b}$ & $30.10 \pm 3.49^{b}$ & $42.89 \pm 10.84^{b}$ \\
\hline \multicolumn{5}{|l|}{ Gastric cancer } \\
\hline Non-smokers & $6.53 \pm 1.04^{\mathrm{c}}$ & $8.26 \pm 0.93^{c}$ & $27.09 \pm 3.14^{\mathrm{c}}$ & $44.43 \pm 6.65^{\mathrm{c}}$ \\
\hline
\end{tabular}

Values are given as mean \pm S.D from 50 subjects in each group; Values not sharing a common superscript letter differ significantly at $\mathrm{p}<0.05(\mathrm{DMRT})$

Table IV: Activities of erythrocyte antioxidant enzymes SOD, CAT, GPx and GST in healthy control and gastric cancer subjects

\begin{tabular}{|c|c|c|c|c|}
\hline Parameters & $\begin{array}{c}\text { SOD } \\
\left(\text { Unit }^{\mathrm{A}} / \mathrm{mgHb}\right) \\
\end{array}$ & $\begin{array}{c}\text { CAT } \\
\left(\text { Unit }^{\mathrm{B}} / \mathrm{mg} \mathrm{Hb}\right) \\
\end{array}$ & $\begin{array}{c}\mathrm{GPx} \\
\left(\mathrm{Unit}^{\mathrm{C}} \mathrm{mg} / \mathrm{Hb}\right) \\
\end{array}$ & $\begin{array}{c}\mathrm{GST} \\
\left(\mathrm{Unit}^{\mathrm{D}} \mathrm{mg} / \mathrm{Hb}\right) \\
\end{array}$ \\
\hline \multicolumn{5}{|l|}{ Control } \\
\hline Non-smokers & $3.71 \pm 0.26^{\mathrm{a}}$ & $69.5 \pm 6.60^{\mathrm{a}}$ & $9.28 \pm 1.59^{\mathrm{a}}$ & $2.31 \pm 0.28^{\mathrm{a}}$ \\
\hline Smokers & $2.55 \pm 0.12^{b}$ & $51.4 \pm 9.03^{b}$ & $6.89 \pm 0.84^{b}$ & $1.78 \pm 0.33^{\mathrm{b}}$ \\
\hline \multicolumn{5}{|l|}{ Gastric cancer } \\
\hline Non-smokers & $2.14 \pm 0.11^{\mathrm{c}}$ & $43.7 \pm 7.70^{c}$ & $6.03 \pm 0.71^{\mathrm{c}}$ & $1.42 \pm 0.27^{\mathrm{c}}$ \\
\hline Smokers & $1.94 \pm 0.10^{\mathrm{d}}$ & $32.2 \pm 6.04^{\mathrm{d}}$ & $3.74 \pm 0.68^{\mathrm{d}}$ & $0.82 \pm 0.32^{\mathrm{d}}$ \\
\hline
\end{tabular}

Values are given as mean \pm S.D from 50 subjects in each group; Values not sharing a common superscript letter differ significantly at $\mathrm{p}<0.05$ (DMRT); A-One unit of activity was taken as the enzyme reaction, which gave $50 \%$ inhibition of NBT reduction in one minute; $\mathrm{B}-$ $\mu$ mole of $\mathrm{H}_{2} \mathrm{O}_{2}$ consumed/minute; $\mathrm{C}-\mu \mathrm{g}$ of $\mathrm{GSH}$ consumed/min; D $-\mu$ moles of CDNB - GSH conjugate formed/min. Values are given as mean \pm S.D from 50 subjects in each group

Table V: Plasma ( $\beta$ carotene vitamin $\mathrm{E}$ and vitamin $\mathrm{C}$ in healthy control (non-smokers and smokers) and gastric cancer (nonsmokers and smokers) subjects

\begin{tabular}{lccc}
\hline Parameters & $\begin{array}{c}\text { Vitamin A } \\
\beta \text {-Carotene } \\
(\mathrm{mg} / \mathrm{dL})\end{array}$ & $\begin{array}{c}\text { Vitamin E } \\
(\mathrm{mg} / \mathrm{dL})\end{array}$ & $\begin{array}{c}\text { Vitamin C } \\
(\mathrm{mg} / \mathrm{dL})\end{array}$ \\
\hline Control & & & \\
Non-smokers & $0.77 \pm 0.080^{\mathrm{a}}$ & $1.22 \pm 0.28^{\mathrm{a}}$ & $1.09 \pm 0.21^{\mathrm{a}}$ \\
Smokers & $0.46 \pm 0.064^{\mathrm{b}}$ & $0.78 \pm 0.16^{\mathrm{b}}$ & $0.72 \pm 0.17^{\mathrm{b}}$ \\
Gastric cancer & & & \\
Non-smokers & $0.44 \pm 0.061^{\mathrm{b}}$ & $0.63 \pm 0.13^{\mathrm{c}}$ & $0.54 \pm 0.13^{\mathrm{c}}$ \\
Smokers & $0.29 \pm 0.056^{\mathrm{c}}$ & $0.41 \pm 0.16^{\mathrm{d}}$ & $0.38 \pm 0.12^{\mathrm{d}}$ \\
\hline
\end{tabular}

Values are given as mean \pm S.D from 50 subjects in each group; Values not sharing a common superscript letter differ significantly at $\mathrm{p}<0.05(\mathrm{DMRT})$

There is epidemiological evidence that free radicals and antioxidants may be important components in the pathophysiology of gastric cancer. Lipid peroxidation has been implicated in a number of deleterious effects such as increased membrane rigidity, osmotic fragility, decreased cellular deformability, reduced erythrocyte survival and lipid fluidity ${ }^{6,19}$.

Lipid peroxides were found in healthy subjects suggesting that oxygen free radicals are also produced in the normal state probably as a consequence of normal metabolic processes. In our study we found increased TBARS concentration in plasma and erythrocytes from patients with gastric cancer, indicating that there is a non-specific overproduction of free radicals in some phases of those diseases. This may also be due to excessive generation of lipid peroxidation products in tumor tissue, and subsequent release of these products into the circulation. A reason for increased lipid peroxidation in patients with gastric cancer may be a poor enzymatic and non-enzymatic antioxidant defense system ${ }^{19-22}$. In our study, the extent of plasma lipid peroxidation was markedly higher in gastric cancer patients with smoking than nonsmoking carcinoma patients. Tobacco smoke has 
been reported to stimulate $\mathrm{H}_{2} \mathrm{O}_{2}$ and hydroxyl radicals. Aromatic amines, nitrogen oxide, heavy metal ions like $\mathrm{Cd}^{2+}$ and other potential carcinogens found in smoke can induce lipid peroxidation. Nicotine, an addictive substance present in tobacco has been demonstrated to inhibit apoptosis, thereby facilitating cancer development ${ }^{23}$.

The impaired antioxidant system may favor accumulation of free radicals. It has been found that low levels of essential antioxidants in the circulation are associated with an increased risk of cancer $^{24}$. Alternatively it is possible that the antioxidant system is impaired as a consequence of an abnormality in the antioxidative metabolism due to the cancer processes. Decreased activity of SOD has been reported in pathological conditions including malignancies ${ }^{19}$. Superoxide, a highly diffusible radical, can transverse membranes and cause deleterious effects at sites far from the tumor. It is possible that lipid peroxidation of erythrocytes in patients with gastric cancer is due to $\mathrm{O}_{2}{ }^{-}$ produced by the tumor as well as low activity of SOD within red cells ${ }^{6}$.

The antioxidant enzyme, catalase, is widely distributed in all animal tissues and high activity is found in the red blood cells. It has been suggested to play an important role in the protection of erythrocytes against oxidative stress. Studies have shown that the administration of CAT results in protection against $\mathrm{H}_{2} \mathrm{O}_{2}$-mediated lipid peroxidation. Several studies have shown a decrease in CAT activity in cancer as part of a severe impairment of antioxidant systems in cancerous tissues ${ }^{19,20}$. The increase in the erythrocyte lipid peroxidation levels in patients with gastric cancer can be correlated to the reduction in CAT activity.

Glutathione and glutathione dependent enzymes have been known to be of central importance in the detoxification of peroxides, hydroperoxides, xenobiotics and drugs. Oxidative stress may cause changes in the glutathione redox state in cancer tissues. It has been reported that MDA might react with amino acid residues of proteins and lead to their oxidative modification. This aldehyde also has the ability to increase oxidative stress by promoting cellular consumption of glutathione and by inactivating glutathione peroxidase ${ }^{23}$.

GSH, a widely distributed cellular reductant is a metabolic regulator and putative indicator of health. Blood glutathione levels are believed to be predicators of morbidity and mortality. GSH plays a key role in protecting cells against electrophiles and free radicals. GSH can act directly as a free radical scavenger by neutralising $\mathrm{HO}^{\circ}$, or indirectly by repairing initial damage to macromolecules inflicted by $\mathrm{HO}^{\circ}$. This is essential in the maintenance of protein and non-protein $\mathrm{SH}$ group in reduced form. A marked decrease in GSH content in circulation has been reported in several diseases including malignancies ${ }^{24,25}$. The lower GSH levels in seen in gastric cancer patients support the hypothesis that glutathione status is inversely related to malignant transformation.

Glutathione peroxidase and glutathione $S$ transfersae that use GSH as a substrate play a crucial role in protection against the deleterious effects of oxygen free radicals and xenobiotics. The formation of GSSG during the reduction of peroxides, or as a consequence of free radical scavenging, is potentially cytotoxic. Thereby, the activity of GR represents one of the most important determinants of cellular protection against oxidative $\operatorname{stress}^{26}$. Robinson et al. ${ }^{27}$, found a tendency for blood GPx to decrease with cancer progression. We also observed significant decrease in the activities GPx and GST in patients with gastric cancer. The depletion of GSH may be responsible for the decreased activity of antioxidant enzymes in gastric cancer patients.

$\beta$-Carotene is a unique chain-breaking lipid-soluble antioxidant, which traps the peroxyl radicals. In the chronic tobacco smokers decreased plasma level of $\beta$-carotene was associated with increased risk of stomach cancer. An increased risk of stomach cancer among smokers has been observed in numerous case-control and cohort studies and is consistent with our study too ${ }^{28}$. Vitamin $\mathrm{E}$ is the major intracellular lipophilic chain breaker and efficient antioxidant capable of trapping peroxyl radicals and quenching free radicals. Vitamin $\mathrm{E}$ is essential for the integrity of red cells and scavenging of free radicals by this antioxidant has been suggested to be the most critical step in defending erythrocytes from oxidative damage. The decreased level of plasma $\alpha$-tocopherol was associated with increased risk of stomach cancer. Increased lipid peroxidation of erythrocytes in cancer patients in the present study can be attributed largely to low levels of vitamin $E^{6,19,29}$.

Ascorbic acid is an important antioxidant in plasma because it disappears faster than other antioxidants when plasma is exposed to oxygen free radicals. The vitamin $\mathrm{C}$ concentration is lower in blood plasma of cigarette smokers compared to nonsmokers, possibly due to increased turnover of the vitamin, which increased oxidant stress in smokers. It could also be due to its increased consumption during recycling of vitamin $\mathrm{E}$ or $\beta$-carotene that is directly oxidized in the course of scavenging free radicals and reactive oxidant species in cigarette smoke $^{30}$. Our present study has demonstrated the 
effect of chronic smoking, which enhanced lipid peroxidation in gastric carcinoma with concomitant failure of both the plasma and erythrocyte antioxidants defense mechanism. In conclusion, our findings indicate that chronic smoking is one of the causative factors for the development of gastric carcinoma.

\section{References}

1. Forman D, Burley VJ. Gastric cancer: Global pattern of the disease and an overview of environmental risk factors. Best Pract Res Clin Gastroenterol. 2006; 20: 633- 49.

2. Liu TS, Wang Y, Chen SY, Sun YH. An updated metaanalysis of adjuvant chemotherapy after curative resection for gastric cancer. EJSO. 2008; 34: 1208-16.

3. Parkin DM, Bray F, Ferlay J, Pisani P. Global cancer statistics. Cancer J Clin. 2005; 55: 74-108.

4. Koul A, Bhatia V, Bansal MP. Effect of alphatocopherol on pulmonary antioxidant defense system and lipid peroxidation in cigarette smoke inhaling mice. BMC 2001; 2: 14-18.

5. Mirvish SS. Role of N-nitroso compounds (NOC) and $\mathrm{N}$-nitrosation in etiology of gastric, esophageal, nasopharyngeal and bladder cancer and contribution to cancer of known exposures to NOC. Cancer Lett. 1995; 93: 17-48.

6. Uma C. Erythrocyte lipid peroxidation and antioxidants in cigarette smokers. Cell Biochem Funct. 2000; 18: 99102.

7. Yagi K. Lipid peroxides and human diseases. Chem Phys Lipids 1978; 45: 337-51.

8. Donnan SK. The thiobarbituric acid test applied to tissues from rats treated in various ways. J Biol Chem. 1950; 182: 415-19.

9. Kakkar PS, Das B, Viswanathan PN. A modified spectrophotometric assay of superoxide dismutase. Indian J Biochem. Biophys. 1984; 21: 130-32.

10. Sinha KA. Colorimetric assay of catalase. Anal Biochem. 1972; 47: 389-94.

11. Rotruck JT, Pope AL, Ganther HE, Swanson AB, Hafeman DG, Hoekstra WG. Selenium: Biochemical roles as a component of glutathione peroxidase. Science 1973; 179: 588-90.

12. Habig WH, Pabst MJ, Jakoby WB. Glutathione-Stransferases, the first enzymatic step in mercapturic acid formation. J Biol Chem. 1974; 249: 7130-39.

13. Ellman GL. Tissue sulfhydryl groups. Arch Biochem Biophys. 1959; 82: 70-77.

14. Beutler E, Kelley BM. The effect of sodium nitrate on red cell glutathione. Experientia 1963; 19: 96-97.

15. Bradley DW, Hombeck CL. Clinical evaluation and improved TFA micro method for plasma and serum vitamin (A) $\beta$-carotene. Biochem Med. 1973; 7: 78-86.
16. Baker H, Frank O, De Angelis B, Feingold S. Plasma tocopherol in man at various times after ingesting free or acetylated tocopherol. Nutr Rep Int. 1980; 21: 531-36.

17. Roe HJ, Kuether CA. Detection of ascorbic acid in whole blood and urine through the 2, 4-dinitrophenylhydrazine derivative of dehydroascorbic acid. J Biol Chem. 1943; 147: 399- 407.

18. Duncan BD. Multiple range test for correlated and heteroscedastic means. Biometrics 1957; 13: 359-64.

19. Arivazhagan S, Kavitha K, Nagini S. Erythrocyte lipid peroxidation and antioxidants in gastric cancer patients. Cell Biochem Funct. 1997; 15: 15-18.

20. Codandabany C. Erythrocyte lipid peroxidation and antioxidants in cigarette smokers. Cell Biochem Funct. 2000; 18: 99-102.

21. Skrzydlewska E, Kozuszko B, Sulkowska M, Bogdan Z, Kozlowski M, Snarska J, Puchalski Z, Sulkowski S, Skrzydlewski Z. Antioxidant potential in esophageal, stomach and colorectal cancers. Hepatogastroenterology 2003; 50: 126-31.

22. Hwang TS, Choi HK, Han HS. Differential expression of manganese superoxide dismutase, copper/zinc superoxide dismutase, and catalase in gastric adenocarcinoma and normal gastric mucosa. EJSO. 2007; 33: 474-79.

23. Nishino Y, Inoue M, Tsuji I, Wakai K, Nagata C, et al. Tobacco smoking and gastric cancer risk: An evaluation based on a systematic review of epidemiologic evidence among the Japanese population. Jpn J Clin Oncol. 2006; 36: 800-07.

24. Scibior D, Skrzycki M, Podsiad M, Czeczot H. Glutathione level and glutathione-dependent enzyme activities in blood serum of patients with gastrointestinal tract tumors. Clin Biochem. 2008; 41: 852-58.

25. Della Rovere F, Granata A, Saija A. SH groups and glutathione in cancer patient's blood. Anticancer Res. 2000; 20: 1595-98.

26. Masella R, Di Benedetto R, Vari R, Filesi C, Giovannini C. Novel mechanisms of natural antioxidant compounds in biological systems: Involvement of glutathione and glutathione-related enzymes. J Nutr Biochem. 2005; 16: 577-86.

27. Robinson ME, Godfrey PJ, Thompson LD, Rea HM, Van Riji AM. Blood selenium and glutathione peroxidase activity in normal subjects and in surgical patients with and without cancer in New Zealand. Am J Clin Nutr. 1979; 32: 1477-85.

28. Block G. Vitamin $\mathrm{C}$ and cancer prevention: The epidemiologic evidence. Am J Clin Nutr. 1991; 53: 270S-82S.

29. Jedrychowski W, Boeing H, Wahrendorf J, et al. Vodka consumption, tobacco smoking and risk of gastric cancer in Poland. Int J Epidemiol. 1993; 22: 606-13.

30. Frei B, England L, Ames BN. Ascorbate is an outstanding antioxidant in human blood plasma. Proc Natl Acad Sci. 1989; 86: 6377-81. 